OPEN ACCESS

Edited by:

Pierre Val, CNRS, France

Reviewed by: Jean Mazella, CNRS, France

David B. Wilson,

Washington University, USA

*Correspondence: Bruno Ragazzon, Institut Cochin, 24 rue du FaubourgSaint-Jacques, Paris 75014, France bruno.ragazzon@inserm.fr

Specialty section: This article was submitted to Cellular Endocrinology, a section of the journal Frontiers in Endocrinology

Received: 14 April 2015 Accepted: 26 May 2015 Published: 09 June 2015

Citation:

Drougat L, Omeiri $H$, Lefèvre $L$ and Ragazzon B (2015) Novel insights into the genetics and pathophysiology of adrenocortical tumors. Front. Endocrinol. 6:96. doi: 10.3389/fendo.2015.00096

\section{Novel insights into the genetics and pathophysiology of adrenocortical tumors}

\author{
Ludivine Drougat ${ }^{1,2,3}$, Hanin Omeiri ${ }^{1,2,3}$, Lucile Lefèvre ${ }^{1,2,3}$ and Bruno Ragazzon ${ }^{1,2,3 *}$ \\ ${ }^{1}$ U1016, INSERM, Institut Cochin, Paris, France, ${ }^{2}$ UMR8104, CNRS, Paris, France, ${ }^{3}$ Université Paris Descartes, Sorbonne \\ Paris Cité, Paris, France
}

Adrenocortical tumors (ACTs) are typically unilateral and can be classified as benign adrenocortical adenomas (ACAs) or malignant adrenocortical cancers (ACCs). In rare cases, tumors may occur in both adrenal glands as micronodular hyperplasia (primary pigmented nodular adrenal dysplasia) or as macronodular hyperplasia (primary bilateral macronodular adrenal hyperplasia, PBMAH). The study of certain tumor predisposition syndromes has improved our understanding of sporadic ACTs. Most ACAs are associated with abnormalities of the CAMP signaling pathway, whereas most ACCs are linked to alterations in IGF2, TP53, or the Wnt/Bcatenin pathways. Over the past year, singlenucleotide polymorphism array technology and next-generation sequencing have identified novel genetic alterations in ACTs that shed new light on the molecular mechanisms of oncogenesis. Among these are somatic mutations of PKA catalytic subunit alpha gene (PRKACA) in ACA, germline, and somatic mutations of armadillo repeat containing 5 gene (ARMC5) in primary bilateral macronodular adrenal hyperplasia and somatic alterations of the E3 ubiquitin ligase gene ZNRF3 in ACC. This review focuses on the recent discoveries and their diagnostic, prognostic, and therapeutic implications.

Keywords: adrenocortical adenoma, hyperplasia, adrenocortical carcinoma, PRKACA, ARMC5, ZNRF3

\section{Introduction}

The pathogenic mechanisms underlying adrenocortical tumors (ACTs) are complex and heterogeneous. The most common ACT is benign, unilateral, non-secreting (adrenocortical adenomas, ACAs-NS), and often discovered incidentally. ACTs exist in the bilateral form but are much less frequent. The symptoms due to ACT are caused by steroid excess (Cushing's syndrome) in the case of secreting benign tumors. The aggressive and deadly forms of ACT are adrenocortical cancers (ACCs) but have an overall low incidence of appearance. The clinical consequences of ACC can be due to steroid oversecretion, tumor growth, or metastasis. ACCs are rare and show heterogeneity in malignancy, in levels of hormone secretion, and in tumor progression. It is also difficult to predict evolution and prognosis although these cancers are globally associated to poor outcome.

Till now, the majority of genetic and molecular alterations of benign tumors has been closely linked to abnormalities in the CAMP signaling pathway. Somatic and germline mutations were identified in actors of the CAMP pathway as the PRKAR1A gene (regulatory subunit of the CAMPdependent protein kinase A) (1,2), GNAS gene ( $\alpha$ subunit of the stimulatory G protein) (3), and the PDE11A/8B genes (cAMP-degrading phosphodiesterase $11 A$ and $8 B$, respectively) $(4,5)$. Other alterations modulating the $\mathrm{CAMP} / \mathrm{PKA}$ pathway activity that stimulates steroidogenesis are present 
in ACA. For example, ectopic expression of the gastric inhibitory polypeptide receptor (GIPR) in the human adrenal gland causes significant hypercortisolemia after meal ingestion and leads to Cushing's syndrome $(6,7)$. Ectopic expression of other receptors belonging to binding $\mathrm{G}$ protein-coupled receptors classes such as vasopressin, serotonin, and catecholamine receptors have been described in the bilateral hyperplasias of the adrenal cortex and cortisol-secreting adenomas (ACA-S) $(8,9)$. In contrast to ACA, ACCs have been related to alterations in various pathways such as IGF2, TP53, or Wnt/ $\beta$ catenin. Initially, progress in identifying genes involved in sporadic ACT came mainly from the study of rare familial cases (10-12): TP53 tumor suppressor gene and its predisposition's locus on chromosome 17p13.1 involved in Li-Fraumeni syndrome; the imprinted gene encoding the insulin-like growth factor IGF2, located on chromosome 11p15.5 and associated with Beckwith-Wiedemann syndrome, germline PRKAR1A mutations identified in Carney complex. Moreover, somatic mutations in the CTNNB1 gene have been reported in both benign and malignant ACTs (13). However, alterations in these several genes are identified only in subgroups of ACA and ACC. Over the last 5 years, the development of high-throughput sequencing has revealed several frequent alterations in genes not previously described, underlying new insights in the pathogenesis of benign and malignant forms of ACT. For example, a hotspot somatic mutation in the PKA catalytic subunit alpha gene (PRKACA) has been identified in ACA (14), germline, and somatic mutations of armadillo repeat containing 5 gene $(A R M C 5)$ have been described in patients with primary bilateral macronodular adrenal hyperplasia (PBMAH) (15), and somatic alterations in the E3 ubiquitin ligase gene ZNRF3 were recently identified in ACC (16). In this review, we aim to give an overview of recent advances in the genetics of ACT, focusing on the latest driver genes identified, and therefore improving our understanding of the pathophysiology of these tumors.

\section{Adrenocortical Adenomas}

Prior to the introduction of next-generation sequencing, mutations in some genes such as GNAS or PRKAR1A had been reported in ACA-S. Activating mutations of the GNAS alpha subunit (17) and PRKAR1A-inactivating mutations (18) promote the cAMP pathway activation. CTNNB1-activating mutations had been found in ACA-NS and ACA-S but their prevalence was higher among ACA-NS $(13,19,20)$. However, these mutations accounted for only a subset of ACA. Recently, Beuschlein and collaborators identified a hotspot mutation in PRKACA gene through whole-exome sequencing in ACA-S (14). The somatic mutation, p.L206R/c.617A > G was present in more than one-third of the examined tumors. This result was confirmed by four other groups, which has reported the same recurrent mutation in the PRKACA gene (21-24). This mutation occurs in the C-terminus of the activation segment in the $p+1$ loop of PRKACA protein (Figure 1A). This region is a specific binding site for the interaction between catalytic and regulatory subunits of PKA (25). The p.L206R point mutation results in the introduction of a voluminous and positively charged amino acid that inhibits the formation of stable complexes between subunits of PKA $(23,24,26)$. This mutation prevents the interaction of the catalytic subunit of PKA with the regulatory subunit, resulting in an increased phosphorylation of substrates and finally, in an excessive steroidogenic activity (Figure 2A). The consequence of this lack of interaction has been shown for both RIA (PRKAR1A) and RIIB (PRKAR2B) regulatory subunits (26). L206R mutation of PRKACA in ACA-S was associated with more severe phenotypes (Cushing's syndrome) (14). Another mutation in the PRKACA gene, Leu199_Cys200insTrp, identified only in one study, has the same effect on the stability of the PKA complex (14, 26) (Figures 1A and 2A).

Adrenal cortex and cortisol-secreting adenomas are characterized by a high occurrence of PRKACA-activating mutations. However, other mutations in GNAS and CTNNB1 genes are found in some ACA-S without PRKACA mutations and are mutually exclusive $(21,23)$. The hotspot mutation in the PRKACA gene seems to be sufficient to alter the endocrine and proliferative systems in ACA-S and represents the main genetic risk factor associated with this type of tumor (14, 21-24).

\section{Primary Bilateral Macronodular Adrenal Hyperplasia}

Primary bilateral macronodular adrenal hyperplasia described first in 1964 is a rare type of bilateral ACTs leading to adrenal Cushing's syndrome (33). PBMAH are often revealed incidentally during radiological examinations or by the presence of overt Cushing's syndrome. Both adrenal glands are enlarged massively with the presence of numerous macronodules. This adrenal disorder is usually diagnosed in patients aged between 40 and 60. In addition to ectopic expression of $\mathrm{G}$ protein-coupled receptors, it has been described in PBMAH an abnormal expression of paracrine factors (34-36). For instance, recently, an ACTH production by adrenocortical cells was reported in a large series of PBMAH, which can play a role in cortisol hypersecretion (36). Despite the fact that most cases of PBMAH appeared to be sporadic, some familial cases were reported, supporting the idea of a germline hereditary factor. Mutations or variants of some genes involved in the cAMP signaling pathway have been identified as in GNAS, $P D E 11 A$, and $P D E 8 B$ genes but are only present in a limited fraction of PBMAH cases.

Combining single-nucleotide polymorphism (SNP) array and whole-genome sequencing, the first gene predisposing to PBMAH in adults has been recently identified (15). The most frequent somatic chromosome alteration in PBMAH was a loss of heterozygosity $(\mathrm{LOH})$ at $16 \mathrm{p}$ and, the most frequent mutation identified was in ARMC5 gene, located at 16p11.2. ARMC5 alterations were detected in tumors obtained from 18 of 33 patients who had undergone surgery (55\%). In all cases, both alleles of ARMC5 carried alteration: one germline and the other somatic. For some cases with an ARMC5 germline mutation, different nodules from one or both adrenal glands were analyzed. In each case, the same germline mutation was detected in all nodules and associated with a nodule-specific second somatic ARMC5 alteration ( $\mathrm{LOH}$, nonsense or missense mutation). The discovery of ARMC5 alterations establishes the first direct genetic link to PBMAH. The pattern of mutations suggests a "two-hit" model of a tumor suppressor gene, responsible for a hereditary predisposition syndrome. Subsequent studies confirm the recurrent mutation of 


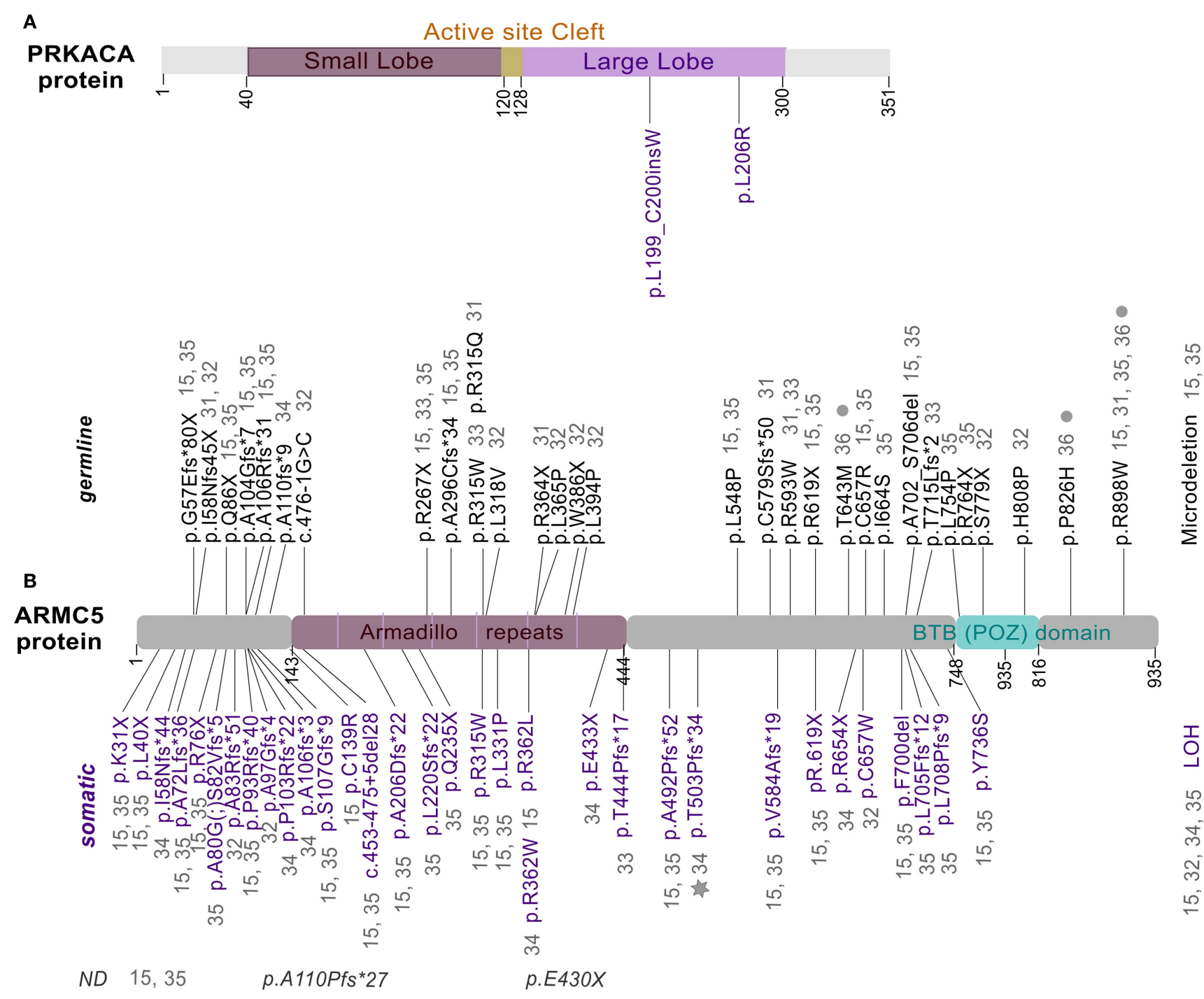

C

ZNRF3 protein
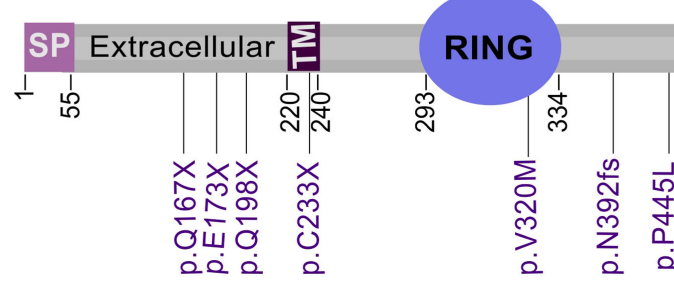

Intracellular

FIGURE 1 | Location of mutations in PRKACA, ARMC5, and ZNRF3 Full length of PRKACA (A), ARMC5 (B), and ZNRF3 (C) proteins were represented with mutations identified in ACA-S (14, 21-24), PBMAH (15, 27-32), and ACC (16), respectively. Somatic mutations are shown in purple, while germline mutations in black. Gray star and filled gray circles represent mutations identified in a meningioma (31) and in patients with

hyperaldosteronism (32), respectively. ND, germline or somatic status not determined.
ARMC5 in family members with PBMAH (27-30). In these various studies, the percentage of ARMC5 mutations reaches $25 \%$ in index cases of PBMAH. Recently, the high frequency of alterations in the $A R M C 5$ gene has been confirmed in a large cohort of 98 patients with PBMAH, including operated and non-operated patients (31). Up to now, these recent studies identified - in patients with PBMAH - in addition to $\mathrm{LOH}$ and a microdeletion, a total of 61 different mutations in ARMC5: 27 germinal, 30 somatic, two which 





have been identified at somatic and germline levels in different cases (p.R315W and p.R619X) and two without status available (Figure 1B). All these mutations can be found all along the protein in different domains. Two of the germline mutations are found in several index cases and in at least three studies suggesting a founder effect: p.R267X and p.R898W (15, 27-32).

The ARMC5 encodes a protein of 935 amino acids and the peptide sequence reveals two distinctive domains: ARM domain in the $\mathrm{N}$-terminal and a BTB/POZ in the C-terminal (Bric-a-Brac, Tramtrack, Broad-complex/Pox virus, and Zinc finger) (Figure 1B). These domains are highly conserved through evolution and have been shown to be involved in mediating protein-protein interactions, but targeted proteins recognition by these domains is not understood yet. The mechanism of ARMC5 action is unknown because no study has ever been focused on its biological function, and no diseases have been associated with the ARMC5 gene until now. Recent functional study on ARMC5 gene, performed in the human adrenocortical cells $\mathrm{H} 295 \mathrm{R}$, showed that $A R M C 5$ gene silencing alters the expression of genes involved in steroidogenesis leading to a global decreased of cortisol secretion (15) (Figure 2B). These data are consistent with previous expression-profile studies $(37,38)$. It is therefore likely that, despite the reduced secretory capacity of each cell, the overall production of cortisol was increased because of the large adrenal mass. All data describing ARMC5 mutations show that patients suffering from PBMAH have a phenotype more severe than patients without ARMC5 mutation $(15,31)$. Patients with ARMC5 mutations present with larger tumor volumes, increased numbers of tumor nodules, and more severe hypercortisolism (31). Recently, ARMC5 mutations have been associated with another steroid hypersecretion. Indeed, six patients of $56(10.7 \%)$ with primary hyperaldosteronism had germline mutations in the ARMC5 gene. Among these six patients, two suffered from PBMAH (32).

The genomic and functional data indicate that ARMC5 has a role of tumor suppressor gene because two inactivating mutations seem necessary to develop PBMAH and human cells (H295R and $\mathrm{HeLa}$ ) transfected with non-mutated ARMC5 resulted in cell death (Figure 2B). In contrast, this effect was not observed with missense mutations. This suggests that ARMC5 plays a significant role in cell apoptosis $(15,31)$.

Bilateral adrenalectomy is considered as the single treatment of choice for PBMAH, the finding of ARMC5 gene is promising for the discovery of new therapeutic perspectives. Interestingly, a somatic mutation in ARMC5 gene has also been found in a meningioma in patients with an ARMC5 germline mutation and a PBMAH (30). These data suggest that genetic alterations of the $A R M C 5$ gene may cause the development of different associated tumors with PBMAH. With the recent advances in the genetic methods, it is possible to imagine that future studies will reveal cases with ARMC5 mutations in other types of tumors without PBMAH. Now, it is necessary to better know the functional role of the ARMC5 protein in order to understand the impact of these mutations on the initiation and/or development of PBMAH.

Mutations in the DOT1L (DOT1-like histone H3K79 methyltransferase) and HDAC9 (histone deacetylase 9) genes have also been found in patients with PBMAH. Unlike ARMC5 mutations, their frequency is lower and appeared only in two and one cases, respectively. These new mutations seem to define a little subgroup of PBMAH without ARMC5 mutations (21). DOT1L and HDAC9 are methyltransferase and histone deacetylase, respectively; these two nuclear proteins are involved in the transcriptional regulation. Further investigations will help to delineate the importance of these three genes in the adrenal function. In regard to the high frequency (20\%) of mutations in ARMC5 gene in all index cases analyzed, its systematic genetic screening appears to be important for patients with PBMAH or Cushing syndrome. This screening can be used for early detection of PBMAH in family members with no clinical evidence.

\section{Adrenocortical Cancer}

ACC is a rare and highly aggressive endocrine tumor that affects one to two persons per 1 million of the population per year (39). The prognosis of ACC is very poor, with a 5-year survival rate under 35\% in most series (40-43). Currently, surgery is the only curative therapy available. Medical treatments, including the adrenolytic drug mitotane and cytotoxic chemotherapy, show only limited therapeutic potential (44). The rarity of ACC is a limiting factor in the progress to understand the pathophysiology of this tumor. Up to now, somatic inactivating mutations of the tumor suppressor gene TP53 and activating mutations of the protooncogene $\beta$-catenin (CTNNB1) were the most frequent mutations identified in ACC $(13,42,45,46)$.

Recently, a cohort of 122 ACC, from the European Network for the Study of Adrenal Tumors (ENSAT), was analyzed by SNP array. Fifty-five of these 122 ACC have also been analyzed by a combination of other genomic approaches, including exome sequencing, DNA methylation, mRNA expression arrays, and miRNA sequencing. Candidate driver genes were validated by targeted sequencing in all tumors. This work confirmed recurrent alterations in the known drivers CTNNB1 and TP53 and revealed new genes not previously reported to be altered in ACC. Strikingly, ZNRF3 (Zinc and ring finger protein 3) was the most frequently altered gene $(21 \%)$. In a majority of cases, homozygous deletions of ZNRF3 were observed but few somatic inactivating mutations and two missense mutations were also identified (16) (Figure 1C).

ZNRF3 and its homolog RNF43 (ring finger protein 43) encode proteins with E3 ubiquitin ligase activity that have recently been described as cell-surface transmembrane E3 ubiquitin ligases, acting as negative feedback regulators of $\mathrm{Wnt} / \beta$-catenin signaling. ZNRF3 and RNF43 contain a signal peptide, an extracellular domain for R-spondin (RSPO)-binding, a single transmenbrane helix, a cytoplasmic really interesting new gene (RING) finger domain, and a C-terminal tail. It has been demonstrated that ZNRF3/RNF43 are associated with the Wnt receptors (Frizzled, FZD), which results in a multi-ubiquitination of lysines in the intracellular domain of FZD and then their internalization and degradation in lysosomes $(47,48)$. RSPO are secreted proteins known to potentiate the Wnt signaling. Various membrane proteins have been reported to bind RSPO, including FZD and LRP6, LGR4/5/6, Kremen, Syndecan, and ZNRF3/RNF43 (49). Several models of RSPO signaling have been proposed. Recently, published data indicate that the ZNRF3/RNF43-mediated membrane clearance of FZD is reversed upon addition of RSPO $(47,49,50)$. Once bound to its receptor (LGR5), RSPO are believed to decoy ZNRF3, thus permitting strong $\beta$-catenin signaling (Figure 2C). 
It has been shown that ZNRF3 protein expression is down regulated in gastric adenocarcinoma tissues compared with adjacent normal gastric tissues (51). Recurrent deletion of three regions in chromosome 22 was identified in osteoblastoma, one of these regions contains ZNRF3 (52). Moreover, the deletion of ZNRF3 and RNF43 in the intestinal epithelium in mouse induces the development of adenoma with an increased nuclear $\beta$-catenin and an increased expression of Wnt/ $\beta$-catenin target genes (48).

Interestingly alterations of $Z N R F 3$ and $C T N N B 1$ are completely exclusive in ACC (16), suggesting that ZNRF3 alterations might play a crucial role in tumorigenesis by activating also the Wnt/ $\beta$ catenin signaling pathway. Taken together, $37 \%$ of ACC samples harbored an alteration affecting the Wnt pathway. These data strongly suggest that in ACC, ZNRF3 is a tumor suppressor gene related to the Wnt pathway. ACC with altered ZNRF3 showed transcriptional activation of $\beta$-catenin targets, but this activation was weaker than in CTNNB1-mutated tumors (16). However, till now, ACCs are the cancers described with the most frequent ZNRF3 alterations, suggesting a specific mechanism of tumorigenesis into the adrenal cortex tissue. Future functional studies are needed to investigate its role in adrenocortical cells.

\section{Conclusion}

Analyses of inherited syndromes associated with an increased risk adrenocortical tumorigenesis, coupled with recent advances in

\section{References}

1. Groussin L, Kirschner LS, Vincent-Dejean C, Perlemoine K, Jullian E, Delemer B, et al. Molecular analysis of the cyclic AMP-dependent protein kinase A (PKA) regulatory subunit 1A (PRKAR1A) gene in patients with Carney complex and primary pigmented nodular adrenocortical disease (PPNAD) reveals novel mutations and clues for pathophysiology: augmented PKA signaling is associated with adrenal tumorigenesis in PPNAD. Am J Hum Genet (2002) 71:1433-42. doi:10.1086/344579

2. Kirschner LS, Carney JA, Pack SD, Taymans SE, Giatzakis C, Cho YS, et al. Mutations of the gene encoding the protein kinase A type I-alpha regulatory subunit in patients with the Carney complex. Nat Genet (2000) 26:89-92. doi: $10.1038 / 79238$

3. Fragoso MCBV, Domenice S, Latronico AC, Martin RM, Pereira MAA, Zerbini $\mathrm{MCN}$, et al. Cushing's syndrome secondary to adrenocorticotropin-independent macronodular adrenocortical hyperplasia due to activating mutations of GNAS1 gene. J Clin Endocrinol Metab (2003) 88:2147-51. doi:10.1210/jc.2002-021362

4. Horvath A, Boikos S, Giatzakis C, Robinson-White A, Groussin L, Griffin KJ, et al. A genome-wide scan identifies mutations in the gene encoding phosphodiesterase 11A4 (PDE11A) in individuals with adrenocortical hyperplasia. Nat Genet (2006) 38:794-800. doi:10.1038/ng1809

5. Horvath A, Giatzakis C, Tsang K, Greene E, Osorio P, Boikos S, et al. A cAMP-specific phosphodiesterase (PDE8B) that is mutated in adrenal hyperplasia is expressed widely in human and mouse tissues: a novel PDE8B isoform in human adrenal cortex. Eur J Hum Genet (2008) 16:1245-53. doi:10.1038/ejhg.2008.85

6. Lacroix A, Bolté E, Tremblay J, Dupré J, Poitras P, Fournier H, et al. Gastric inhibitory polypeptide-dependent cortisol hypersecretion - a new cause of Cushing's syndrome. NEngl JMed (1992) 327:974-80. doi:10.1056/NEJM199210013271402

7. Reznik Y, Allali-Zerah V, Chayvialle JA, Leroyer R, Leymarie P, Travert G, et al. Food-dependent Cushing's syndrome mediated by aberrant adrenal sensitivity to gastric inhibitory polypeptide. N Engl J Med (1992) 327:981-6. doi:10.1056/ NEJM199210013271403

8. Lacroix A, Bourdeau I, Lampron A, Mazzuco TL, Tremblay J, Hamet P. Aberrant G-protein coupled receptor expression in relation to adrenocortical overfunction. Clin Endocrinol (Oxf) (2010) 73:1-15. doi:10.1111/j.1365-2265.2009.03689.x sequencing technology, have improved our understanding of ACT. Recent advances in genomic tools, especially sequencing technologies, have yielded new findings in three types of ACT. Alterations in genes not previously reported were identified: somatic mutations of PRKACA gene in ACA, germline and somatic mutations of $A R M C 5$ gene in $\mathrm{PBMAH}$, and somatic alterations of ZNRF3 gene in ACC.

It would be worth pursuing functional studies on these genes in order to understand the impact of these alterations on the initiation and/or development of ACT. The identification of signaling pathways playing a major role in ACT development would help to develop new targeted therapies, which are dramatically needed for the management of patients harboring these tumors, especially for ACC.

\section{Acknowledgments}

We would like to acknowledge the COMETE Network (Programme Hospitalier de Recherche Clinique Grant AOM95201), the Seventh Framework Programme (FP7/2007-2013/259735), the Association pour la Recherche sur le Cancer (SFI20111203542), the Ligue contre le cancer (RS12/75-105), the Cony-Maeva foundation and the Fonds de Dotation Patrick de Brou de Laurière, which supported our lab activity. LL is a recipient of the Fondation de la Recherche Médicale (FDT20140931179). HO is a recipient of the Ligue contre le cancer (GB/MA/CD-11282).

9. Miyamura N, Taguchi T, Murata Y, Taketa K, Iwashita S, Matsumoto K, et al. Inherited adrenocorticotropin-independent macronodular adrenal hyperplasia with abnormal cortisol secretion by vasopressin and catecholamines: detection of the aberrant hormone receptors on adrenal gland. Endocrine (2002) 19:319-26. doi:10.1385/ENDO:19:3:319

10. Lefèvre L, Bertherat J, Ragazzon B. Adrenocortical growth and cancer. Compr Physiol (2015) 5:293-326. doi:10.1002/cphy.c140010

11. Lerario AM, Moraitis A, Hammer GD. Genetics and epigenetics of adrenocortical tumors. Mol Cell Endocrinol (2014) 386:67-84. doi:10.1016/j.mce.2013.10.028

12. Libé R, Bertherat J. Molecular genetics of adrenocortical tumours, from familial to sporadic diseases. Eur J Endocrinol (2005) 153:477-87. doi:10.1530/ eje.1.02004

13. Tissier F, Cavard C, Groussin L, Perlemoine K, Fumey G, Hagneré A-M, et al. Mutations of beta-catenin in adrenocortical tumors: activation of the Wnt signaling pathway is a frequent event in both benign and malignant adrenocortical tumors. Cancer Res (2005) 65:7622-7. doi:10.1158/0008-5472.CAN-05-0593

14. Beuschlein F, Fassnacht M, Assié G, Calebiro D, Stratakis CA, Osswald A, et al. Constitutive activation of PKA catalytic subunit in adrenal Cushing's syndrome. N Engl J Med (2014) 370:1019-28. doi:10.1056/NEJMoa1310359

15. Assié G, Libé R, Espiard S, Rizk-Rabin M, Guimier A, Luscap W, et al. ARMC5 mutations in macronodular adrenal hyperplasia with Cushing's syndrome. NEngl J Med (2013) 369:2105-14. doi:10.1056/NEJMoa1304603

16. Assié G, Letouzé E, Fassnacht M, Jouinot A, Luscap W, Barreau O, et al. Integrated genomic characterization of adrenocortical carcinoma. Nat Genet (2014) 46:607-12. doi:10.1038/ng.2953

17. Libé R, Mantovani G, Bondioni S, Lania AG, Pedroni C, Beck-Peccoz P, et al. Mutational analysis of PRKAR1A and Gs(alpha) in sporadic adrenocortical tumors. Exp Clin Endocrinol Diabetes (2005) 113:248-51. doi:10.1055/s-2005-837651

18. Bertherat J, Groussin L, Sandrini F, Matyakhina L, Bei T, Stergiopoulos S, et al. Molecular and functional analysis of PRKAR1A and its locus (17q22-24) in sporadic adrenocortical tumors: $17 \mathrm{q}$ losses, somatic mutations, and protein kinase A expression and activity. Cancer Res (2003) 63:5308-19.

19. Bonnet S, Gaujoux S, Launay P, Baudry C, Chokri I, Ragazzon B, et al. Wnt/ $\beta$ catenin pathway activation in adrenocortical adenomas is frequently due to somatic CTNNB1-activating mutations, which are associated with larger and 
nonsecreting tumors: a study in cortisol-secreting and -nonsecreting tumors. J Clin Endocrinol Metab (2011) 96:E419-26. doi:10.1210/jc.2010-1885

20. Tadjine M, Lampron A, Ouadi L, Bourdeau I. Frequent mutations of beta-catenin gene in sporadic secreting adrenocortical adenomas. Clin Endocrinol (Oxf) (2008) 68:264-70. doi:10.1111/j.1365-2265.2007.03033.x

21. Cao Y, He M, Gao Z, Peng Y, Li Y, Li L, et al. Activating hotspot L205R mutation in PRKACA and adrenal Cushing's syndrome. Science (2014) 344:913-7. doi:10.1126/ science. 1249480

22. Di Dalmazi G, Kisker C, Calebiro D, Mannelli M, Canu L, Arnaldi G, et al. Novel somatic mutations in the catalytic subunit of the protein kinase $\mathrm{A}$ as a cause of adrenal Cushing's syndrome: a European multicentric study. J Clin Endocrinol Metab (2014) 99:E2093-100. doi:10.1210/jc.2014-2152

23. Goh G, Scholl UI, Healy JM, Choi M, Prasad ML, Nelson-Williams C, et al. Recurrent activating mutation in PRKACA in cortisol-producing adrenal tumors. Nat Genet (2014) 46:613-7. doi:10.1038/ng.2956

24. Sato Y, Maekawa S, Ishii R, Sanada M, Morikawa T, Shiraishi Y, et al. Recurrent somatic mutations underlie corticotropin-independent Cushing's syndrome. Science (2014) 344:917-20. doi:10.1126/science. 1252328

25. Yang J, Garrod SM, Deal MS, Anand GS, Woods VL, Taylor S. Allosteric network of cAMP-dependent protein kinase revealed by mutation of Tyr204 in the P+1 loop. J Mol Biol (2005) 346:191-201. doi:10.1016/j.jmb.2004.11.030

26. Calebiro D, Hannawacker A, Lyga S, Bathon K, Zabel U, Ronchi C, et al. PKA catalytic subunit mutations in adrenocortical Cushing's adenoma impair association with the regulatory subunit. Nat Commun (2014) 5:5680. doi:10.1038/ ncomms 6680

27. Faucz FR, Zilbermint M, Lodish MB, Szarek E, Trivellin G, Sinaii N, et al. Macronodular adrenal hyperplasia due to mutations in an armadillo repeat containing 5 (ARMC5) gene: a clinical and genetic investigation. JClin Endocrinol Metab (2014) 99:E1113-9. doi:10.1210/jc.2013-4280

28. Alencar GA, Lerario AM, Nishi MY, Mariani BM, Almeida MQ, Tremblay J, et al. ARMC5 mutations are a frequent cause of primary macronodular adrenal hyperplasia. J Clin Endocrinol Metab (2014) 99:E1501-9. doi:10.1210/ jc.2013-4237

29. Gagliardi L, Schreiber AW, Hahn CN, Feng J, Cranston T, Boon H, et al. ARMC5 mutations are common in familial bilateral macronodular adrenal hyperplasia. J Clin Endocrinol Metab (2014) 99:E1784-92. doi:10.1210/jc.2014-1265

30. Elbelt U, Trovato A, Kloth M, Gentz E, Finke R, Spranger J, et al. Molecular and clinical evidence for an ARMC5 tumor syndrome: concurrent inactivating germline and somatic mutations are associated with both primary macronodular adrenal hyperplasia and meningioma. J Clin Endocrinol Metab (2015) 100:E119-28. doi:10.1210/jc.2014-2648

31. Espiard S, Drougat L, Libé R, Assié G, Perlemoine K, Guignat L, et al. ARMC5 mutations in a large cohort of primary macronodular adrenal hyperplasia: clinical and functional consequences. J Clin Endocrinol Metab (2015). doi:10.1210/ jc.2014-4204

32. Zilbermint M, Xekouki P, Faucz FR, Berthon A, Gkourogianni A, Helene Schernthaner-Reiter M, et al. Primary aldosteronism and ARMC5 variants. J Clin Endocrinol Metab (2015). doi:10.1210/jc.2014-4167

33. Kirschner MA, Powell RD, Lipsett MB. Cushing's syndrome: nodular cortical hyperplasia of adrenal glands with clinical and pathological features suggesting adrenocortical tumor. J Clin Endocrinol Metab (1964) 24:947-55. doi:10.1210/ jcem-24-10-947

34. Bertherat J, Contesse V, Louiset E, Barrande G, Duparc C, Groussin L, et al. In vivo and in vitro screening for illegitimate receptors in adrenocorticotropin-independent macronodular adrenal hyperplasia causing Cushing's syndrome: identification of two cases of gonadotropin/gastric inhibitory polypeptide-dependent hypercortisolism. J Clin Endocrinol Metab (2005) 90:1302-10. doi:10.1210/ jc.2004-1256

35. Louiset E, Contesse V, Groussin L, Cartier D, Duparc C, Perraudin V, et al. Expression of vasopressin receptors in ACTH-independent macronodular bilateral adrenal hyperplasia causing Cushing's syndrome: molecular, immunohistochemical and pharmacological correlates. J Endocrinol (2008) 196:1-9. doi:10.1677/ JOE-07-0413

36. Louiset E, Duparc C, Young J, Renouf S, Tetsi Nomigni M, Boutelet I, et al. Intraadrenal corticotropin in bilateral macronodular adrenal hyperplasia. NEngl J Med (2013) 369:2115-25. doi:10.1056/NEJMoa1215245
37. Antonini SR, Baldacchino V, Tremblay J, Hamet P, Lacroix A. Expression of ACTH receptor pathway genes in glucose-dependent insulinotrophic peptide (GIP)-dependent Cushing's syndrome. Clin Endocrinol (Oxf) (2006) 64:29-36. doi:10.1111/j.1365-2265.2005.02411.x

38. Assie G, Louiset E, Sturm N, René-Corail F, Groussin L, Bertherat J, et al. Systematic analysis of $\mathrm{G}$ protein-coupled receptor gene expression in adrenocorticotropin-independent macronodular adrenocortical hyperplasia identifies novel targets for pharmacological control of adrenal Cushing's syndrome. J Clin Endocrinol Metab (2010) 95:E253-62. doi:10.1210/jc.2009-2281

39. Else T, Kim AC, Sabolch A, Raymond VM, Kandathil A, Caoili EM, et al. Adrenocortical carcinoma. Endocr Rev (2014) 35:282-326. doi:10.1210/ er.2013-1029

40. Abiven G, Coste J, Groussin L, Anract P, Tissier F, Legmann P, et al. Clinical and biological features in the prognosis of adrenocortical cancer: poor outcome of cortisol-secreting tumors in a series of 202 consecutive patients. JClin Endocrinol Metab (2006) 91:2650-5. doi:10.1210/jc.2005-2730

41. Allolio B, Fassnacht M. Clinical review: adrenocortical carcinoma: clinical update. J Clin Endocrinol Metab (2006) 91:2027-37. doi:10.1210/jc.2005-2639

42. Libè R, Fratticci A, Bertherat J. Adrenocortical cancer: pathophysiology and clinical management. Endocr Relat Cancer (2007) 14:13-28. doi:10.1677/erc.1.01130

43. Luton JP, Cerdas S, Billaud L, Thomas G, Guilhaume B, Bertagna X, et al. Clinical features of adrenocortical carcinoma, prognostic factors, and the effect of mitotane therapy. NEngl J Med (1990) 322:1195-201. doi:10.1056/NEJM199004263221705

44. Fassnacht M, Terzolo M, Allolio B, Baudin E, Haak H, Berruti A, et al. Combination chemotherapy in advanced adrenocortical carcinoma. N Engl J Med (2012) 366:2189-97. doi:10.1056/NEJMoa1200966

45. Gaujoux S, Grabar S, Fassnacht M, Ragazzon B, Launay P, Libé R, et al. $\beta$-catenin activation is associated with specific clinical and pathologic characteristics and a poor outcome in adrenocortical carcinoma. Clin Cancer Res (2011) 17:328-36. doi:10.1158/1078-0432.CCR-10-2006

46. Ragazzon B, Libé R, Gaujoux S, Assié G, Fratticci A, Launay P, et al. Transcriptome analysis reveals that $\mathrm{p} 53$ and $\{$ beta $\}$-catenin alterations occur in a group of aggressive adrenocortical cancers. Cancer Res (2010) 70:8276-81. doi:10.1158/0008-5472. CAN-10-2014

47. Hao H-X, Xie Y, Zhang Y, Charlat O, Oster E, Avello M, et al. ZNRF3 promotes Wnt receptor turnover in an R-spondin-sensitive manner. Nature (2012) 485:195-200. doi:10.1038/nature11019

48. Koo B-K, Spit M, Jordens I, Low TY, Stange DE, van de Wetering M, et al. Tumour suppressor RNF43 is a stem-cell E3 ligase that induces endocytosis of Wnt receptors. Nature (2012) 488:665-9. doi:10.1038/nature11308

49. Xie Y, Zamponi R, Charlat O, Ramones M, Swalley S, Jiang X, et al. Interaction with both ZNRF3 and LGR4 is required for the signalling activity of R-spondin. EMBO Rep (2013) 14:1120-6. doi:10.1038/embor.2013.167

50. De Lau W, Peng WC, Gros P, Clevers H. The R-spondin/Lgr5/Rnf43 module: regulator of Wnt signal strength. Genes Dev (2014) 28:305-16. doi:10.1101/ gad.235473.113

51. Zhou Y, Lan J, Wang W, Shi Q, Lan Y, Cheng Z, et al. ZNRF3 acts as a tumour suppressor by the Wnt signalling pathway in human gastric adenocarcinoma. J Mol Histol (2013) 44:555-63. doi:10.1007/s10735-013-9504-9

52. Nord KH, Nilsson J, Arbajian E, Vult von Steyern F, Brosjö O, Cleton-Jansen A-M, et al. Recurrent chromosome 22 deletions in osteoblastoma affect inhibitors of the Wnt/beta-catenin signaling pathway. PLoS One (2013) 8:e80725. doi:10.1371/ journal.pone. 0080725

Conflict of Interest Statement: The authors declare that the research was conducted in the absence of any commercial or financial relationships that could be construed as a potential conflict of interest. The Associate Editor Pierre Val declares that, despite having collaborated with author Bruno Ragazzon, the review process was handled objectively and no conflict of interest exists.

Copyright $\odot 2015$ Drougat, Omeiri, Lefèrre and Ragazzon. This is an open-access article distributed under the terms of the Creative Commons Attribution License (CC BY). The use, distribution or reproduction in other forums is permitted, provided the original author(s) or licensor are credited and that the original publication in this journal is cited, in accordance with accepted academic practice. No use, distribution or reproduction is permitted which does not comply with these terms. 